DOI https://doi.org/10.18551/rjoas.2017-02.07

\title{
THE EFFECT OF ORGANIZATIONAL COMMITMENT TOWARD TURNOVER INTENTION AT NARADA SCHOOL, INDONESIA
}

\author{
Pawirosumarto Suharno*, Setiawan Ketut, Setyadi, Elmi Farida \\ University of Mercu Buana, Indonesia \\ *E-mail: suharno70@yahoo.com
}

\begin{abstract}
This study aims to identify and analyze the influence of Organizational Commitment (Affective Commitment, Continuance Commitment, and Normative Commitment) against Turnover Intention. Being a quantitative research, the population and sample in this study are teachers at Narada School in Jakarta, Indonesia. The data are collected by survey method using a questionnaire distributed to all teachers in kindergarten, elementary, secondary, and high schools with a total of 100 samples. The data are analyzed to test the validity, reliability, and linear regression. The results show that Affective Commitment on the dimension of Identification has the most dominant influence on Turnover Intention at Narada School. There is a significant effect simultaneously of Affective Commitment, Continuance Commitment, and Normative Commitment to Turnover Intention at Narada School. This study is worth valued as Narada School is a Buddhism-based school which puts forward the spirit of service to God. Thus, we will see whether this Buddhism value is still embraced by the school's staffs or has been replaced with other (usually financial) motives.
\end{abstract}

\section{KEY WORDS}

Organizational commitment, affective commitment, continuance commitment, normative commitment, turnover intention.

Elementary and Secondary Education both play an important role in the series of formal learning. Schools as a formal education unit need to organize and provide procedures and rules in accordance with the needs of education. This is in accordance with the 1945 Constitution Article 31 Paragraph 1 confirming that every child is entitled to the same education as mandated.

Narada School is one of formal education institutions in Jakarta. It provides elementary to secondary level of education. Established in 2005, Narada School has undergone vicissitudes. Narada School opens up its education gradually, starting from kindergarten, elementary, then junior and senior high school after the first batch of their primary school students graduated. Education available at Narada School is kindergarten 1-6 years old, primary school 6-12 years old, junior high school 12-16 years old and senior high school 1620 years.

Admission of new students at Narada School in general has increased from 2004 to 2015 as shown by Figure 1. It shows that the admission of new students at Narada School from 2005 to 2015 increased. Increasing number of students at Narada School then requires management to increase the number of human resources (HR) including teachers and educators (back office).

The increasing number of students is one indicator of successes; however, there are problems that occur with the increasing level of turnover in Narada School. Narada School turnover rate in the average is $25 \%$ since 2013 to 2015 .

To learn more about the problem due to high rate of turnover, we conducted a pre-research. This was conducted on 15 employees (educators) as follows: three people from Pre-School, three people from Elementary School, three people from Junior High School, three people from Senior High School, and three people from Back Office. The results of pre-research are presented in Table 1. 


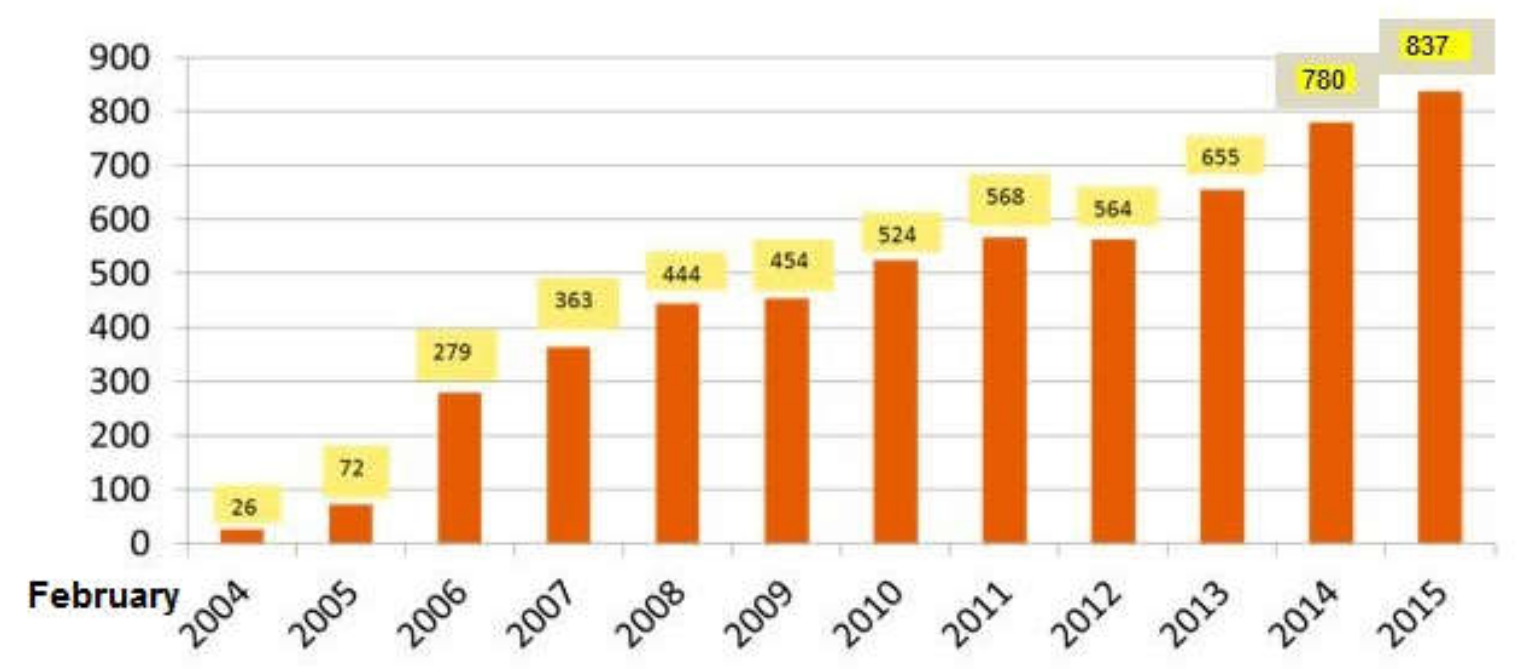

Figure 1 - Admission of new students at Narada School

(Source: Academic Division of Narada School, 2016)

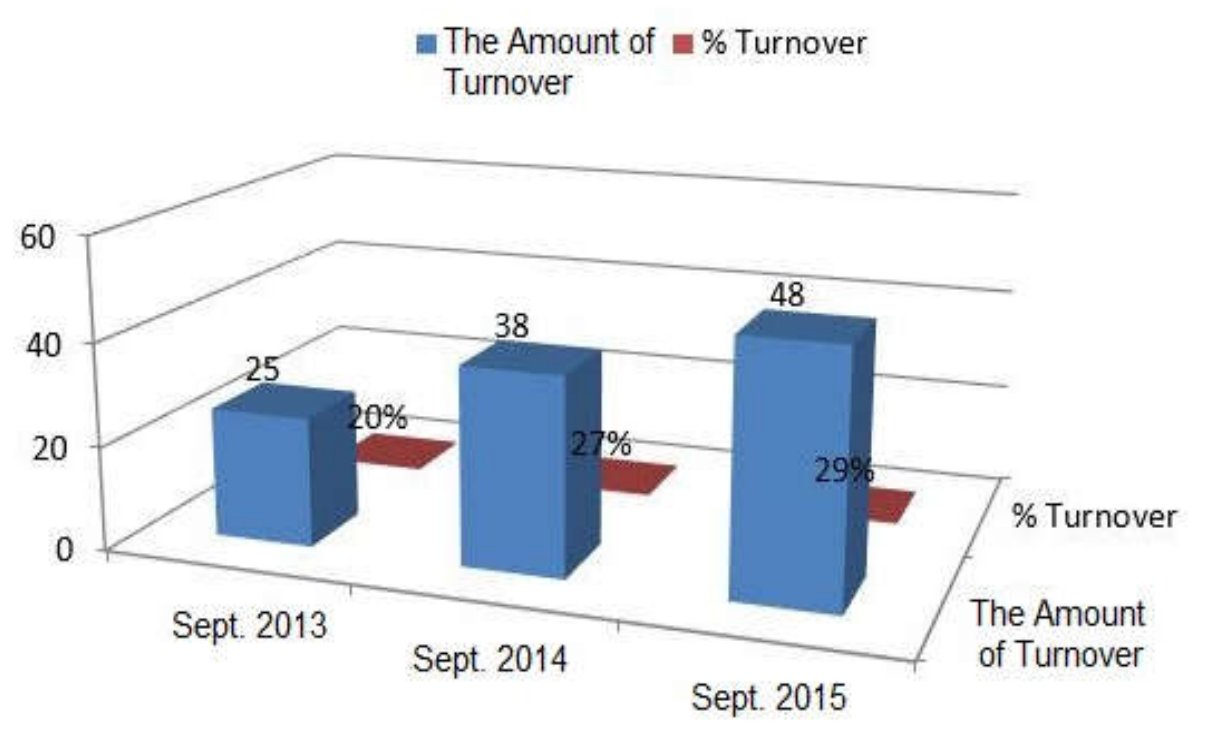

Figure 2 - Turnover at Narada School (Source: HRD Division at Narada School, 2016)

Table 1 show that the problem often arises based on the pre-research is related to organizational commitment as much as $53 \%$. The problems associated with organizational commitment are Affective Commitment, Continuance Commitment, and Normative Commitment of employees at Narada School. This is the reason for our study on Turnover Intention at Narada School.

Table 1 - The Results of Pre-research at Narada School (Source: Setiawan, 2016)

\begin{tabular}{|l|c|c|}
\hline \multicolumn{1}{|c|}{ Variable } & Number of People & Percentage \\
\hline Leadership style & 3 & 20 \\
\hline Organizational culture & 2 & 13 \\
\hline $\begin{array}{l}\text { Organizational commitment } \\
\text { Affective commitment } \\
\begin{array}{l}\text { Continuance commitment } \\
\text { Normative commitment }\end{array}\end{array}$ & 8 & 53 \\
\hline Job satisfaction & 1 & 6,7 \\
\hline Motivation & 1 & 6,7 \\
\hline
\end{tabular}




\section{LITERATURE REVIEW}

Turnover Intention. Turnover Intention by some management experts including Culpepper (2011) is the best predictor to identify the behavior of turnover among employees of an organization. Harrison et al. (2006) state “... presently defined is an employee's preference is to quit his or her job. Real turnover has been looked to be especially likely the result of intentions to withdraw..." and Robbins (2007) states that one's withdrawal of an organization (turnover) can be voluntary turnover or involuntary turnover.

According to Novliadi (2007), factors that influence the occurrence of turnover intention are quite complex and interrelated one to another. These factors include age, length of employment, education level, and attachment to the company. Simamora (2006) explains Turnover Intention is a movement over the limit of membership of an organization that is distinguished in two dimensions: Avoidable Voluntary Turnover and Unavoidable Voluntary Turnover. Mowday (1982) in Alimohammadi et al. (2013) states "Organizational commitment refers to accordance between the goals of the individual and the organization whereby the individual identifies with and extends attempt on representing the general goals of the organization", meaning that organizational commitments refers to individual and organizational goals, where people recognize and seek to present the objectives of an organization.

Organizational Commitment. Organizational Commitment is a situation where an employee favoring a particular organization and its goals, and they are willing to maintain membership in the organization (Robbins and Judge, 2008). Commitment starts with building relationships between individuals, which raises the concern that good preparation will foster understanding and positive perceptions so that people feel able to accept (Parameswari, 2014). Luthan (2006) defines organizational commitment in three stages as follows: 1) a strong desire to remain as a member of a particular organization; 2) the desire to strive according to desire of the organization; and 3) a certain belief and acceptance of the values and goals of the organization. There are three-dimensional components of organizational commitment according to Mayer and Allen (1990) in Luthan (2007), as follows: Affective Commitment, Continuance Commitment, and Normative Commitment.

Affective Commitment. Affective Commitment according to Allen \& Mayer 1997 in Luthan (2007) is a commitment based on the emotional feelings of employees, employee identification, and employee involvement to the organization. Krikwood (2006) explains that Affective Commitment is the result of an agreement between the values and goals of individuals and organizations. They are committed to the organization; they also feel competent to do the job as well as satisfied with their role in the organization. Chu and $\mathrm{Li}$ (2010) find Affective Commitment as a strong emotional bond resulting from an individual's ability to identify its relationship with the organization, and then they will feel closeness to the organization. When people feel the psychological closeness to the organization, then Continuance Commitment will appear. English et al. (2009) find that Affective Commitment is a reinforcing factor for employees with long tenure, although psychologically appears less positive for those employees. According to Allen \& Mayer (1997) in Luthan (2007), Affective Commitment is classified into three dimensions: Emotional Attachment, Identification, and Involvement to the Organization.

Continuance Commitment. Continuance Commitment by Allen \& Mayer (1997) in Luthan (2007) is defined as a component based on employee perceptions about the losses that will be faced, if they leave the organization. Mowday in Sopiah (2008) finds Continuance Commitment as a commitment based on the rational needs. This commitment is formed based on profit and loss, considered on what must be sacrificed to settle on an organization. The key to this commitment is a necessity for survival (need to). Chu and Li (2010) in their study explains that continuance commitment refers to the price to be paid to employees who leave the organization and the commitment of those staying in the organization. Gonzales and Guillen (2007) say there are two dimensions in Continuance Commitment: High Sacrifice and Low Alternative. 
Normative Commitment. Normative Commitment by Allan \& Mayer (1977) in Luthan (2007) is defined as a commitment of employees arising from their sense of obligation to settle in the company or organization. Gonzales and Guillen (2007) add that the Normative Commitment is based on the feeling of obligation to remain a member of an organization based on morality. Mowday in Sopiah (2008) also argues that Normative Commitment is commitment to the organization based on the norms that exist within the employees; their individual beliefs would be the responsibility of the organization. Employees feel that they have to stay because of loyalty. The key to this commitment is the obligation to stay in an organization (ought to).

Chu and Li (2010) have other ideas. Normative Commitment refers to organizational commitment that occurs when employees fully believe in the organization - also called as moral commitment. Albdour and Altarauwneh (2014) explain that Normative Commitment is a commitment based on a sense of obligation to the organization. Employees with a strong normative commitment survive because they think they must do so. Normative Commitment in research conducted by Gonzales \& Guillen (2007) consists of two dimensions: Feeling Obligation and Moral Commitment.

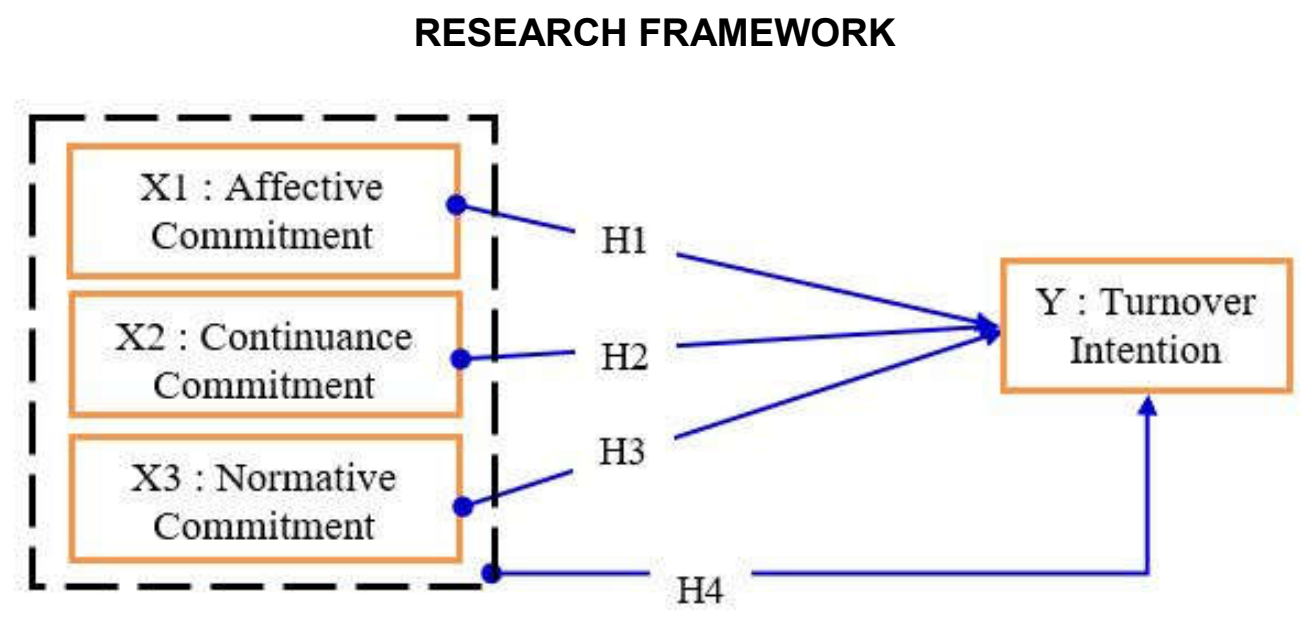

Figure 3 - Research Framework

In this study, there are three independent variables namely Affective Commitment (X1), Continuance Commitment (X2), and Normative Commitment (X3) and the dependent variable of Turnover Intention $(Y)$. We use multiple linear regression analysis to find out, analyze, and explain the effect of the independent variables on the dependent variable either partially or simultaneously as the framework above.

Research Hypothesis. Based on the framework, the hypothesis as a temporary answer to the problems that exist at Narada School will empirically verifiable as below:

$\mathrm{H} 1$ : supposedly there are significant positive effect of Affective Commitment On Turnover Intention.

$\mathrm{H} 2$ : supposedly there are significant positive effect of Continuance Commitment on Turnover Intention.

H3: supposedly there are significant positive effect of Normative Commitment on Turnover Intention.

H4: supposedly there are significant positive effects simultaneously of Affective Commitment, Continuance Commitment, and Normative Commitment on Turnover Intention.

\section{METHODS OF RESEARCH}

The approach in this study was quantitative as the data were concrete, objective, measurable, rational, and systematic. Another name of this quantitative method is the traditional method, positivistic methods (based on positivistic philosophy), and the method of 
discovery (finding a new science and technology). This method is called quantitative research because the data in the form of figures and statistical analysis are used.

Research variables can be defined as an attribute or the nature or value of a person, object, or activity which may have certain variations defined by the researchers to learn and then to draw conclusions (Sugiyono, 2008). Variables in the research could be distinguished as follows:

- Independent variable. This variable is often referred to as the stimulus variables, predictors, or antecedent. The independent variables in this study were the affective commitment (X1), continuance commitment (X2), and normative commitment (X3).

- Dependent variable. This variable is often referred to as the output variable, criteria, or consequence. The dependent variable is affected by the independent variables. The dependent variable in this study was turnover intention $(Y)$.

Measurement of Variable. Measurement of variables was carried out as seen from Table 2.

Table 2 - Dimension of Variable

\begin{tabular}{|c|l|}
\hline Variable & \multicolumn{1}{|c|}{ Dimension } \\
\hline \multirow{2}{*}{ Affective Commitment } & Emotional Attachment \\
\cline { 2 - 2 } & Identification With \\
\cline { 2 - 2 } Continuance Cmmitment & Involvement to the organization \\
\cline { 2 - 2 } & High Sacrifice \\
\hline \multirow{2}{*}{ Normative Commitment } & Few Alternative \\
\cline { 2 - 2 } & Moral Commitment \\
\hline \multirow{2}{*}{ Turnover Intention } & Avoidable Voluntary Turnover \\
\cline { 2 - 2 } & Unavoidable Voluntary Turnover \\
\hline
\end{tabular}

Population and Sample. The population in this study were all teachers, up to 100 people, at Narada School divided into four divisions, consisting of 24 kindergarten teachers, 37 elementary school teachers, and 39 junior and senior high school teachers. The total population was relatively small and relatively easy to reach. The method used was census. Samples were expected to be more likely to approach the real value and are expected to minimize errors or deviations from the population value (Usman and Akbar, 2008).

Data Collection. Data collection was done by means of interviews, questionnaire, observation, and a combination of all three. This study used a combination of data collection techniques through questionnaire, whose answers to the items have been provided by the researchers, and the respondents simply chose the answer. Weighting was done by using a five-point Likert scale, namely Strongly Agree (SA) with a value of 5 , Agree (A) with a value of 4 , Undecided $(U)$ with a value of 3 , Disagree $(D)$ with a value of 2 , and Strongly Disagree (SD) with a value of 1 , for every answer respondents gave in each of the variables studied.

Data Analysis. There were five stages of analysis performed in this study, namely descriptive statistics, quality test on the instrument (validity and reliability test), the classic assumption test (multicollinearity, heteroscedasticity test, normality test, linearity test), data analysis test (multiple regression analysis, F-test, t-test, $\mathrm{R}^{2}$ test), and the correlation between dimensions. Overall activity of data processing and analysis was conducted with the help of a computer using SPSS (Statistical Product for Service Solution) version 22.0.

\section{RESULTS AND DISCUSSION}

Characteristics of Respondents. Questionnaire was distributed between June 1-6, 2016 to all teachers at Narada School. The results of respondents from 100 respondents can be seen from Table 3.

Based on Table 3, of the 100 teachers at Narada School who became the object of study, the majority were women (58\%). Teachers aged less than 30 years dominated the respondents (52\%). It can be said that teachers at Narada School are in their productive age. 
The majority of respondents at Narada School had been working of less than 3 years - there were many new teachers. It was uncommon for teachers to stay there more than 5 years.

Table 3 - Characteristics of Respondents at Narada School 2016 (Source: Setiawan, 2016)

\begin{tabular}{|c|c|c|c|}
\hline \multicolumn{2}{|c|}{ Characteristics } & Number of Respondents & $\%$ \\
\hline \multirow{3}{*}{ Sex } & Male & 42 & 42 \\
\hline & Female & 58 & 58 \\
\hline & Total & 100 & 100 \\
\hline \multirow{4}{*}{ Age } & $<30$ & 52 & 52 \\
\hline & $30-40$ & 37 & 37 \\
\hline & $41-50$ & 10 & 10 \\
\hline & $>50$ & 1 & 1 \\
\hline \multirow{4}{*}{ Education } & Total & 100 & 100 \\
\hline & Senior High School & 4 & 4 \\
\hline & Bachelor (S1) & 86 & 86 \\
\hline & Master's (S2) & 10 & 10 \\
\hline & Total & 100 & 100 \\
\hline \multirow{5}{*}{ Tenure } & $<2$ years & 33 & 33 \\
\hline & $2-3$ years & 34 & 34 \\
\hline & 4-5 years & 9 & 9 \\
\hline & $>5$ & 24 & 24 \\
\hline & Total & 100 & 100 \\
\hline
\end{tabular}

Validity and Reliability. The results of validity and reliability of turnover intention using SPSS version 21 can be seen in Table 4 below.

Table 4 - Validity and Reliability of Instrument (Source: Setiawan, 2016)

\begin{tabular}{|c|c|c|c|c|c|}
\hline Variable & Pearson Corelation & $r_{\text {tabel }}$ & Validity & Cronbach Alpha & Reliable \\
\hline \multicolumn{7}{|c|}{ Turnover Intention (Y) } \\
\hline Avoidable Voluntary Turnover & 0.703 & 0.197 & Valid & 0.901 & Reliable \\
\hline Unvoidale Voluntary Turnover & 0.764 & - & Valid & - & Reliable \\
\hline \multicolumn{7}{|c|}{ Affective Committment (X1) } \\
\hline Emotional Attachment & 0.735 & 0.197 & Valid & 0.891 & Reliable \\
\hline Identification With & 0.635 & - & Valid & - & Reliable \\
\hline Involvment to the Organization & 0.739 & - & Valid & - & Reliable \\
\hline \multicolumn{7}{|c|}{ Continuance Committment (X2) } & Reliable \\
\hline High Sacrifice & 0.504 & 0.197 & Valid & 0.811 & Reliable \\
\hline Low Alternative & 0.579 & - & Valid & - \\
\hline Feeling Obligation & Normative Committment (X3) & Reliable \\
\hline Moral Commitement & 0.637 & 0.197 & Valid & 0.876 & Reliable \\
\hline
\end{tabular}

The variables affective commitment, continuance commitment, normative commitment, and turnover intention showed Pearson Correlation result, which was greater than $r_{\text {-table }}$ 0.197 , thus the dimensions of these variables can be declared as valid. For each variable, the Cronbach Alpha was greater $(>)$ than 0.70 , thus the variables of the study can be said as reliable.

Multiple Regression Analysis. Multiple regression analysis was used to determine the influence of affective commitment, continuance commitment, and normative commitment on turnover intention at Narada School. Hypothesis testing was done by testing the coefficient of determination (R Square), simultaneous significance test (F-Test Statistic), and the individual parameter significance test (t-Test Statistic ). The results of the study are summarized in Table 5.

The coefficient of determination (R2) aims to measure the ability of the model to explain variations in the dependent variable explained by the independent variables. The coefficient of determination ranged from 0 to 1 . The value of R2 is small or close to 0 indicates that the ability of the dependent variable cannot be explained by the independent variables. R2 value close to 1 indicates that the variation of the dependent variables simultaneously can be explained by variations in the independent variables. 
$\mathrm{R}$-square value generated in this study was 0.454 , meaning that $45.4 \%$ of the variable turnover intention can be caused by the variable of affective commitment, continuance commitment, and normative commitment. The remaining $54.6 \%$ is caused by other variables not examined in this study. This indicates that factors beyond the Affective Commitment (X1), Continuance Commitment (X2), and Normative Commitment (X3) can be expected to have a greater contribution to the employee's decision to leave Narada School.

$F$ test is a test of the significance of the equations used to determine how much influence the independent variable has, namely Affective Commitment (X1), Continuance Commitment (X2), and Normative Commitment (X3) simultaneously to the dependent variable $(\mathrm{Y})$ that is Turnover Intention. F-test is required to test the hypothesis proposed in this study.

Table 5 - Regression of Variable X1, X2 and X3 toward Y (Source: Setiawan, 2016)

\begin{tabular}{|c|c|c|c|}
\hline Variable & Coefficients/ R Square & $\mathrm{t}$ & Sig. \\
\hline (Constant) & 3.879 & 7.724 & .000 \\
\hline Affective Commitment & -.395 & -4.351 & .000 \\
\hline Continuance Commitment & -.319 & -2.964 & .004 \\
\hline Normative Commitment & .496 & 4.511 & .000 \\
\hline $\mathrm{R}^{2}$ & 0.454 & - & - \\
\hline F-count & - & 26.559 & 0.000 \\
\hline
\end{tabular}

Based on the table above, it can be seen that the significant value is $0.000>0.05$. That is the result of research conducted at Narada School proved that commitment of the teachers (respresented through affective commitment, continuance commitment, and normative commitment) has a significant effect on turnover intention at Narada School. Hypotheses can be said to be acceptable because significance of the study results do not cross the predetermined standards. This means that in partial affective commitment possessed by teachers significantly influence turnover intention at Narada School.

Data on significance value of Continuance Commitment is $0.004<0.05$. Results of research conducted at Narada School are smaller than the prescribed limit. This means, in partial, Continuance Commitment of teachers also has significant effect on Turnover Intention at Narada School. Normative Commitment results in Table 4 shows a significance value $0.000<0.05$. The results of this study meet the predetermined value, which is not more than 0.05. It can be expressed in partial that Normative Commitment possessed by teachers significantly influence Turnover Intention at Narada School.

Correlation Analysis across Dimensions. In this last part of the discussion, the analysis of the correlation between the dimensions of the research conducted at Narada School will be explained.

Table 6 - Correlation Analysis across Dimensions of Organizational Commitment toward Turnover Intention (Source: Setiawan, 2016)

\begin{tabular}{|c|c|c|c|}
\hline \multirow{2}{*}{ Variable } & \multirow{2}{*}{ Dimension } & \multicolumn{2}{|c|}{ Turnover Intention } \\
\hline & & Avoidable $(\mathrm{YI})$ & Unavoidable (Y2) \\
\hline \multirow{6}{*}{ Affective Commitment } & \multirow{2}{*}{ Emotional Attachment } & -.368 & $-.441^{\pi \prime}$ \\
\hline & & .000 & .000 \\
\hline & \multirow{2}{*}{ Identification with } & -.448 & $-.453^{n}$ \\
\hline & & .000 & .000 \\
\hline & \multirow{2}{*}{ Involvement to the Organization } & $-.265^{\pi}$ & -.414 \\
\hline & & .008 & .000 \\
\hline \multirow{4}{*}{ Continuance Commitment } & \multirow{2}{*}{ High Sacrifice } & -.512 & -.572 \\
\hline & & .000 & .000 \\
\hline & \multirow{2}{*}{ Low Alternative } & $-.285^{n}$ & -.055 \\
\hline & & .004 & .586 \\
\hline \multirow{4}{*}{ Normative Commitment } & \multirow{2}{*}{ Feeling Obligation } & .396 & .121 \\
\hline & & .000 & .231 \\
\hline & \multirow{2}{*}{ Morality } & $.269^{\prime \prime}$ & $.409^{\pi \prime}$ \\
\hline & & .007 & .000 \\
\hline
\end{tabular}


All the variables and dimensions studied at Narada School are set forth in the table. The teachers as respondents answered questions and their answers were processed in SPSS version 21. The results of the questionnaire is presented in Table 6.

Based on the data in Table 6 on correlation across dimensions of Affective Commitment on Turnover Intention, that is the dimension of Emotional Attachment, Identification (0.000), and Involvement to the Organization (0.008), the significance value is smaller or $<0.05$ meaning that there is a significant correlation. If among the dimensions of Emotional Attachment, Identification, and Involvement to the Organization and the dimensions of the dependent variable, Avoidable and Unavoidable Turnover, has significance value less than or $<0.05$, thus it means that there is a significant correlation.

The value of Person Correlation between each dimension of Emotional Attachment, Identification, and Involvement to the Organization of the Avoidable and Unavoidable Turnover Intention has an asterisk; this means that there is a significant correlation between the dimensions connected. Identification is a dimension that has a high influence on Turnover Intention at Narada School. This means that identification in the variable of Affective Commitment needs to be improved in order to reduce Turnover Intention.

Correlation across the dimensions of Continuance Commitment with Turnover Intention in Table 5 shows that High Sacrifice and Low Alternative has a significance value of $0.000<$ 0.05 , which means to have a significant correlation. Furthermore, the dimension of High Sacrifice and Low Alternatives toward the dimensions of Avoidable and Unavoidable Turnover Intention has a significance value of $0.000<0.05$, which means there is a significant correlation.

The dimension Low Alternative has a significance value 0.586 greater than or $>0.05$ meaning the relationship is not so significant on the dimension toward the Unavoidable Turnover Intention. The value of Pearson Correlation for Low Alternative dimension is also not very high correlation, of only 0.055 , which means less significant correlation between the dimensions connected. In this variable, the most influence on Turnover Intention at Narada School is High Sacrifice.

Based on the data in Table 5 for correlation across the dimensions of Normative Commitment to Turnover Intention, that is the dimension of Obligation Feeling and Morality, the significance value is $0.000<0.05$, which means which means a significant correlation. Furthermore, between Feeling Obligation and Morality to the dimension of dependent variable Avoidable and Unavoidable Turnover Intention, it has a significance value $0.000<$ 0.05 , which means there is a significant correlation.

Based on the output value in Table 6, the value of Person Correlation between Feeling Obligation and Morality against Avoidable and Unavoidable Turnover Intention has an asterisk, this means that there is a significant correlation between the dimensions connected. Feeling Obligation has not so high Pearson Correlation value (no asterisk); thus, it can be concluded that the less significant correlation between Feeling Obligation to Unavoidable Turnover Intention. Normative Commitment shows a is a positive Pearson Correlation result; which means that the increase in Normative Commitment of teachers is also followed by Turnover Intention at Narada School. The highest value is at Morality dimension to Unavoidable Turnover Intention $\left(0.409^{* *}\right)$, that was greater than Feeling Obligation toward the two dimensions of Turnover Intention at Narada School.

\section{DISCUSSION OF RESULTS}

Based on the statistical analysis afore-mentioned, the study has resulted in several findings.

The Effect of Affective Commitment toward Turnover Intention. Affective Commitment partially has a significant negative effect on Turnover Intention. These results are consistent with the research conducted by Lew Yew in 2010 in Malaysia published in the journal International Conference on Business and Economics Research vol.1 whose results are low Affective Commitment will lead to increased intention to quit the organization or company. 
Management at Narada School needs to pay more attention on Affective Commitment as low Affective Commitment will affect Turnover Intention. It can be seen from the value of Person Correlation connected between Affective Commitment and Turnover Intention with two asterisks $\left({ }^{* *}\right)$, this means that there is a significant correlation between the dimensions of the Turnover Intention both Avoidable Turnover Intention and Unavoidable Turnover Intention. If no action is taken to solve the problem, it will cause an increase in the number Turnover at Narada School.

Affective Commitment also has a low correlation on the dimension of Identification toward the dimension of Avoidable and Unavoidable Turnover Intention. Identification is a commitment arising because the status or the presence of teachers and employees at Narada School is still so low that affect the desire to move in or out of the Narada School either avoidable or unavoidable.

Narada School Management needs to pay attention and improve Affective Commitment, especially on the dimensions of Identification as the dimension increases the desire to leave Narada School. The higher the Affective Commitment in particular on the dimension of Identification, the lower the Turnover Intention will be. It would be advantageous for Narada School.

The Effect of Continuance Commitment toward Performance. Continuance commitment has a significant negative effect on Turnover Intention at Narada School. This is consistent with previous studies conducted by Jaros and Culpepper (2014) in the Journal of Management \& Organization Volume 20. Their studies concluded that employees remain or stay with the organization because they have no alternative employment.

The Pearson Correlation value for the dimension of High Sacrifice toward Avoidable and Unavoidable Turnover Intention is in the average value of 0.542 and a sign of $\left.{ }^{* *}\right)$ which can be interpreted that this dimension has a significant correlation to Turnover Intention at Narada School.

Continuance commitment based on High Sacrifice is a commitment that is better than the employees who survive because of Low Alternative Low to move. Commitment is what is expected by all organizations. Narada School should be able to understand this and retain employees (teachers) who work at Narada School. Normative commitment also means the big losses employee may receive when choosing to move from an organization. Research conducted at Narada School reveales a fact that Normative Commitment of teachers is high enough to affect Turnover Intention at Narada School.

Narada School Management and Foundation need to pay attention and improve Normative Commitment, especially on the dimension of High Sacrifice. If management or foundation can maintain good relations, then Turnover Intention will decrease and will certainly reduce Turnover - if not, employees will leave Narada School because they have plenty of opportunity to join with other schools or organizations.

The Effect of Normative Commitment toward Turnover Intention. Normative Commitment has positive and significant effect on Turnover Intention. This means that at Narada School, high Normative Commitment also simultaneously results in high Turnover Intention. This is in contrast with previous studies conducted by Sow et al. (2016). The study confirmed that the relationship between Normative Commitment with Turnover Intention was negative and significant.

Normative Commitment in general results in negative correlation, but that does not mean no one has found a positive result. Yasmin and Marzuki (2015) find positive study results as their study found that Affective Commitment and Normative Commitment provided a considerable impact on Turnover Intention in Pakistan. This happens because of internal and external factors that exist in the country, as nurses in Pakistan leave their work because there is somewhere else more promising.

This is in line with research conducted by Faloye (2014) which generated positive results of Normative Commitment on Turnover Intention in Nigeria. In the study, it was also said that in spite of the commitment of employees, they were likely to leave the organization for better career. 
The results in the present study confirm that teachers at Narada School have high Normative Commitment, yet this cannot reduce Turnover Intention - it is even linear. High Turnover Intention can be seen from the age of Narada School teachers that are relatively young (52\%). This may imply either presence or the absence of Normative Commitment does not guarantee teachers to stay. They tend to try new and better opportunities because their opportunities are wide open in outside Narada School.

Normative Commitment on the dimension of Morality Commitment gives dominant influence toward Unavoidable Turnover Intention at Narada School. This means that when teachers have higher moral value, their desire to leave is also higher, and eventually they leave Narada School. Normative Commitment should not be ignored because it will affect Turnover at Narada School.

In general, employees who have Normative Commitment are those who have the least possibility to leave the company (school). The different results in this study in which high Normative Commitment is also followed by high Turnover Intention at Narada School. Management and foundations should be aware of this, when most employees are young age, the turnover will be high, and therefore there should be changes to the system.

The Effect of Affective, Continuance, and Normative Commitment toward Turnover Intention. The results of the study show that Affective Commitment, Continuance Commitment, and Normative Commitment have a simultaneous significant effect toward Turnover Intention. This is evidenced from the value of $F_{\text {count }}>26.599 F_{\text {table }}$ that is greater than 2.85 and the significant value gained is 0.000 less than 0.05 .

This finding is consistent with results of previous studies conducted by Mardiana et al. (2012) in which the study concluded that the increased Affective Commitment, Continuance Commitment, and Normative Commitment would make Turnover Intention to decline and the vice versa.

Research conducted at Narada School shows that the two variables studied have a negative correlation, one variable is positive and significant. This means that Narada School management must understand that there is a problem on commitment, be it Affective Commitment, Continuance Commitment, and Normative Commitment or all of them simultaneously toward Turnover Intention. In accordance with the results of the R-square calculation, the influence of Commitment on Turnover Intention is $45.4 \%$.

Culpepper (2011) mentions Turnover Intention is the best predictor for detecting behavior of turnover. This study proves that $45.4 \%$ of turnover issue that occurs at Narada School has been caused by commitment. The other problems beyond commitment that affect Turnover Intention is even more, as much as $54.6 \%$. However, commitment is the most fundamental problem in the organization - if this is solved, then so is the rest $54.6 \%$.

Low R square value does not mean bad research results (Gujarati et al. in Zega, 2013). Therefore, further research needs to be done to support the results of this study and to find other variables that may affect Turnover Intention at Narada School. The previous study supporting the results of present study is Zega (2013) to the employees of PT. Bahana Achievement. Zega examines the influence of organizational culture, job satisfaction, and organizational commitment toward Turnover Intention resulting in a value of R-square of $24.3 \%$.

The other study has been conducted by Pratiwi (2013) which examines the relationship of personality types on Turnover Intention in loan sales employee at PT. Bank Mandiri (Persero), Tbk. Bandung. From the study, R-square value on the influence of personality types toward Turnover Intention is only $8.37 \%$ and the remaining $91.63 \%$ is influenced by other personality factors not studied.

Foundation and Narada School management needs to set the strategy to improve or grow the commitment of all employees at Narada School. Commitment is the most fundamental perspective within each organization. The organization will work properly if all of its members are committed to achieving the vision and mission determined by the organization.

This section presents the results of research and discussion. The results of the research are the findings from the research conducted, including the results of statistical 
tests for quantitative research using hypothesis. Discussion covers findings of research associated with the theory that has been described in literature review as well as the differences or similarities with previous studies. The implications of both theoretical and practical should be presented here.

\section{CONCLUSION}

Based on the results of the current research, the following conclusions can be drawn:

Affective Commitment has a significant influence on Turnover Intention. Negative results in this study show an inverse relationship between the independent and the dependent variables. This means, the higher the Affective Commitment of Narada School teachers then it could trigger to lower Turnover Intention, and the vice versa. Dimension with dominant influence in the variable is Identification. Improved Identification will further reduce Turnover Intention.

Continuance Commitment has a significant influence on Turnover Intention. Negative results in this study show an inverse relationship between the independent and the dependent variables. This means, the higher the Continuance Commitment of Narada School teachers then it could trigger to increase Turnover Intention, and the vice versa. Dimension with dominant influence in the variable is High Sacrifice. More attention to High Sacrifice dimension will further reduce Turnover Intention.

Normative Commitment has a significant influence on Turnover Intention. Positive results in this study show a direct relationship between the independent and the dependent variables. Normative Commitment of teachers is in line with the high Turnover Intention at Narada School. In some previous research, Normative Commitment is not so dominant in influencing Turnover Intention, yet different result is found at Narada School. Normative Commitment is proportional to the increase in Turnover Intention.

The three independent variables of Affective, Continuance, and Normative Commitment have a significant effect on Turnover Intention at Narada School. Negative results in this study show an inverse relationship between the independent and the dependent variables. This means that these three variables simultaneously can also trigger the employee intention to leave the school (Turnover Intention).

\section{REFERENCES}

1. Albdour, A. \& Altarawneh, I. (2014). Employee and Organization Commitment: Evidence from Jordan. International Journal of Business, ISSN: 1083-4336 pp. 193-212.

2. Alimohammadi, Meysam, N., \& Jamali, A. (2013). Work Motivation and Organizational Commitment Among Iranian Employees. International Journal Of Research In Organizational Behavior And Human Resource Management, 1(3), 2013, pp. 1-12.

3. Allen, N.J. \& Mayer, J.P. (1997). Commitment In The Workplace Theory Research And Application. SAGE Publication, U.S.A.

4. Chu, K-K. \& Li, C-H. (2010). The Study Of The Effects of Identity-Related Judgment, Affective Identification And Continuance Commitment On WOM Behavior. International Journal of Business, Vol. 46. pp. 221-236.

5. Culpepper, R.A. (2011). Three-component commitment and turnover: An examination of temporal aspects. Journal of Vocational Behavior, 79(2), 517-527. USU Repository: 1-34.

6. English, B., Marrison, D. \& Chalon, C. (2009). Moderator Effects of Organizational Tenure On The Relationship Between Psychological Climate And Affective Commitment. Journal of Management Development, Vol. 29 No.4. pp. 394-408.

7. Faloye, D.O. (2014) Organisational Commitment and Turnover Intentions: Evidence From Nigerian Paramilitary Organisation. International Journal of Business and Economic Development (IJBED), Vol. 2 Number 3. pp. 23-34.

8. Gonzales, T.F. \& Guillen, M. (2008). Organizational Commitment. A Proposal for A Wider Ethical Conceptualization Of Normative Commitment. Journal of Business Ethics, 78. pp. 401-414. 
9. Harrison, D. A., Newman, D. A., \& Roth, P. L. (2006). How important are job attitudes? Meta-analytic comparisons of integrative behavioral outcomes and time sequences. Academy of Management Journal, 49. pp. 305-325.

10. Jaros, S. \& Culpepper, R.A. (2014). An Analysis of Meyer and Allen's Continuance Commitment Construct. Journal of Management and Organization, Vol. 20, Issue 01. pp. $79-99$.

11. Krikwood, C. (2006) Effect Of Conscientiousness And Professional Work Autonomy On Nurses' Organizational Commitment (Affective And Continuance) And Intent To Stay. Unpublished Thesis. Queen University. Canada.

12. Lew, T-Y. (2010). Affective Organizational Commitment and Turnover Intention of academics in Malaysia. International Conference on Business and Economics Research, Vol.1. pp. 110-114.

13. Luthan, F. (2007). Organization Behavior. U.S.A.

14. Mardiana, Ria, Yusuf G., Siti H., \& Muhlis H. (2012). The Influence Of Affective, Continuance And Normative Commitments On The Turnover Intentions Of Nurses At Makassar's Private Hospitals In Indonesia. African Journal of Business Management, Vol. 6(38) pp. 10303-10311.

15. Sow, M., Peter, A., \& Mousa, B. (2016). Normative Organization Commitment and its Effects on Employee Retention. Business and Economic Research, ISSN 2162-4860, Vol 6 No.1. pp. 137-147.

16. Novliadi, F. (2007). Intensi Turnover Karyawan Ditinjau Dari Budaya Perusahaan. Tesis. Program Studi Psikologi FK USU. Universitas Sumatra Utara. Medan.

17. Robbins, S.P. (2007). Organizational Behavior. Prentice Hall. New Jersey.

18. Robbins, S.P., Judge, T.A. (2008). Perilaku Organisasi. Edisi Dua Belas. Penerbit Salemba Empat. Jakarta.

19. Simamora, H. (2006). Manajemen Sumber Daya Manusia. Edisi 2. STIE YKPN. Yogyakarta.

20. Sopiah. (2008). Perilaku Organisasi. Yogyakarta.

21. Sugiyono. (2010). Metode Penelitian Pendidikan Pendekatan Kuantitatif, Kualitatif, dan R\&D. Alfabeta. Bandung.

22. Umar, H. (2005). Riset Sumberdaya Manusia Dalam Organisasi. Edisi Revisi \& perluasan. PT. Gramedia Pustaka Utama. Jakarta.

23. Umar, H. (2005). Metode Penelitian. Salemba Empat. Jakarta.

24. Usman, H. \& Akbar, P.S. (2008). Metodologi Penelitian Sosial. PT. Bumi Aksara. Jakarta.

25. Yasmin, K. \& Marzuki, N.A. (2015). Impact of Organizational Commitment on Intention to Quit Among Psychaitric Nurses: Evidence from Pakistan. International Journal of Learning \& Development ISSN 2164-4063 2015, Vol. 5, No. 4. pp. 89-102.

26. Zega, Y.A. (2013). Pengaruh Budaya Organisasi, Kepuasan Kerja dan Komitmen Organisasional terhadap Intensi Keluar (Studi Kasus pada PT Bahana Prestasi). Unpublished Graduate Thesis. Universitas Mercu Buana. Jakarta. 